\title{
Giving Up the World for an Image
}

\author{
Augusto Corrieri
}

W

alter Benjamin writes of the act of playing as being essentially repetitive. The child, almost pedantically, rehearses, repeats, and returns; replaying the same scenes over and over again. What is the sense of this repetition, asks Benjamin? First of all, it allows for a taming of the unknown; repetition allows the child "to master frightening fundamental experiences."1 Secondly, through playing and re-playing, the child develops habit and learns to in-habit the world; it is through repetition, we could say, that we come to be who we are.

The child reaches for the same toy and once again, as before, lifts it up and throws it, only to then repeat this action, always starting from the beginning, with the same pleasure. Using his or her hands, the child literally sculpts for her/himself a rhythmical mode of attention, a way of perceiving and acting in a visible and sensuous world. What is important to note is that, for Benjamin, the particular habit produced by playing with those childhood toys is something that endures in us as adults, indefinitely structuring our relationship to the world. If nothing else, the habit we develop as children persists in the form of nostalgia, and Benjamin ends the essay 'Toys and Play' by asking: "When a modern poet says that everyone has a picture for which he would be willing to give the whole world, how many people would not look for it in an old box of toys?"2

As I read and re-read this last sentence, I start to wonder: what is the image for which I would give up the world? What was my box of toys, the games through which I developed habit, and which still endure in me? For me, as for so many others, the box of toys was constituted by a TV screen, a VCR, and a remote control. The game consisted in playing (with) the filmic flows of sounds and images on the screen.

Play, Pause, Fast-forward, Rewind, and Stop: these are the five basic functions allowing for endless repetitions, delays, and interruptions. Fast-forward through the advertisements; rewind the scene in which the car vanishes back in time; replay it; stop the film for today. Each of the five basic functions corresponds to a familiar sign or better, a shape: the triangle pointing to the right is Play, the square is Stop, and so on. These shapes now seem to me to be lifted straight from a toy box of brightly colored wooden blocks; the ones children use to stack towers and to literally figure out how things fit together and how they fall apart, and what physical and mental actions you must perform in order to assemble and dismantle the world.

Among the many films I played and replayed, the one I consider to be somewhat central is Robert Zemecki's Back to the Future (1985), in which Marty, played by Michael J. Fox, accidentally travels back through time and meets his own future parents. There I am, probably in 1986 or so, watching the film over and over again, endlessly replaying its various scenes, captured not only by the film (the story, the images, the music, etc.) but by the control I can, or cannot, exert over it. By pressing a certain shape-button, I initiate a 


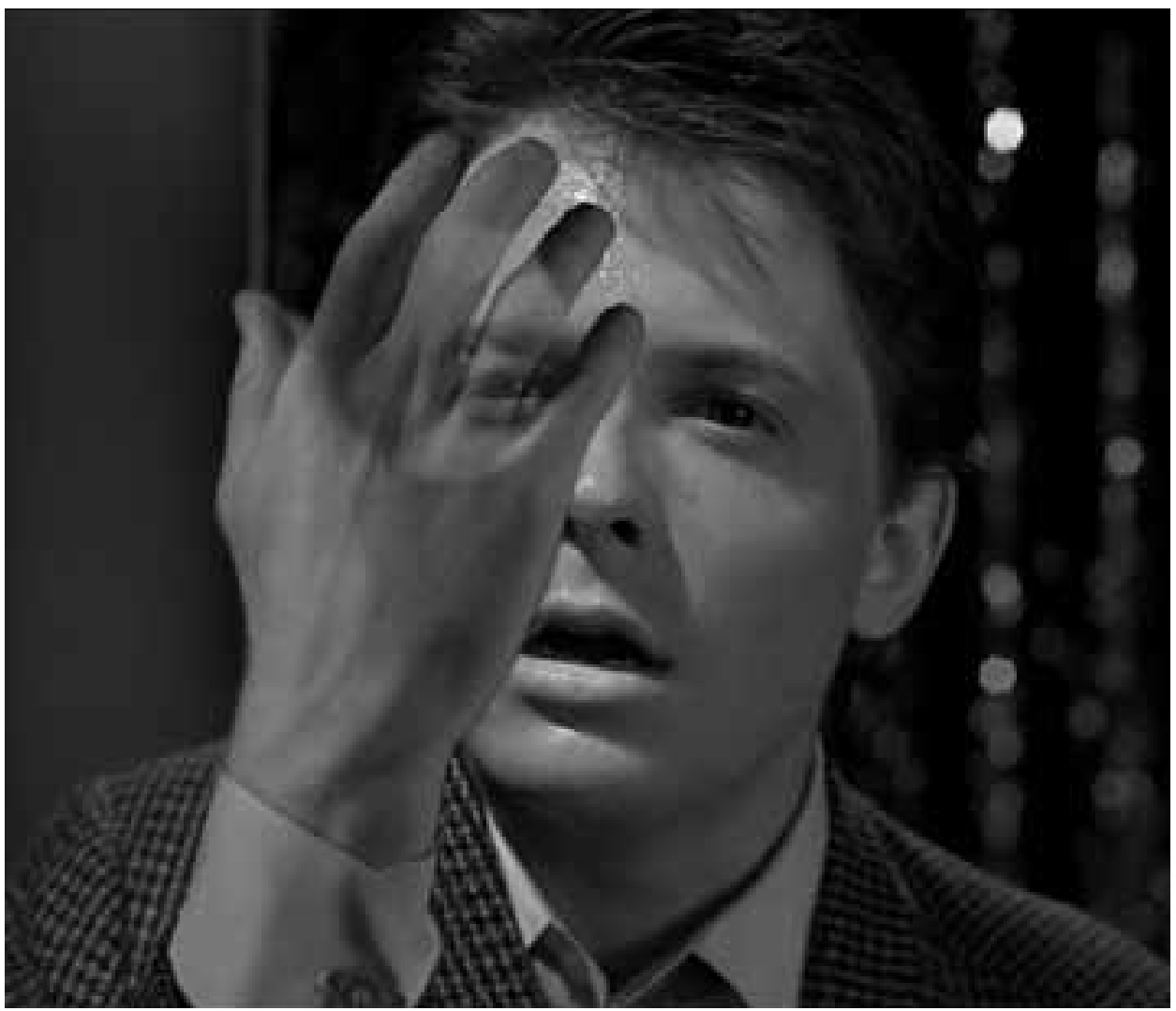

Still from Back to the Future (1985).

particular sequence of sounds and images, thus establishing a bodily connection between my hands and the movements on the screen; but, equally so, I am at the mercy of these sounds and images, as it is these that prompt my various "editing" choices. I wonder whether I chose Back to the Future simply because the film is already all about reversing time flows and replaying sequences over and over again?

The TV screen, the VCR, and the remote control constituted, for so many children growing up in the 1980s, an editing room of sorts; a place for rehearsing not only film sequences but a personal mode of duration - a way of being with the flows of spectacle (mainly films from the United States) — which only later would prove to be a central aspect of contemporary adult life. The child watching a movie is not in a condition of drugged passivity, the inert receiver of an adult-made image. Rather, she is in the process of defining relational dynamics, finding ways to link and unlink body-action-imagesound. As Benjamin writes about our first playing, "these are the rhythms in which we first gain possession of ourselves." ${ }^{3}$

However, it is difficult to really describe the rhythms through which we first came to a definition; it is far easier to recount scenes and instances of the film's narrative (especially when, as in the case of Back to the Future, it is strongly marked by Oedipal dynamics). For example, I remember Marty meeting his future mother; uncannily, they are the same age, and she begins to fall in love with him. And then one evening, stuck in a car, Marty finds 
himself unable to stop his mother from leaning over and kissing him. As I picture my sixyear-old self re-playing this scene, I can imagine this would have been a way for me to master "frightening fundamental experiences," to re-cite Benjamin. ${ }^{4}$

Yet there is one scene (or should I say a rhythm? A mode of duration?) that haunts me above all others. Its endurance in me is equivalent to a nursery rhyme that one cannot forget, for it is those very rhymes that help to form memory in the first place. I am referring to the film's dramatic and existential climax: Marty is now in danger of losing his own life if his future mother and father do not kiss. It is the high school ball and Marty is playing a guitar on-stage. Time is running out on him, and it looks as if his parents may not get together after all. He pulls out a (future) photograph of his brother, his sister, and himself; their image has already vanished, and now his image is slowly beginning to fade too. Marty begins to sweat; we hear his palpitations; he slowly collapses to the ground. With eyes wide open in terror, he gazes upon his own hand and notices that it is becoming translucent. It is as though his own flesh were in the process of turning to celluloid, as if the body were taking on the spectral quality of film itself. I now wonder whether it was through playing this scene that I first saw myself as an image, a phantom of sorts, whose outline can appear and disappear just like the figure on the screen. Was it here that I first rehearsed the flicker of uncertainty? Was it through stilling and reversing this scene that I first rehearsed the oscillation of my own image, the first of many anxious dislocations?

\section{References}

Back to the Future. Directed by Robert Zemeckis. Universal City, CA: Universal Pictures, 1985.

Benjamin, Walter. "Toys and Play: Marginal Notes on a Monumental Work." Walter Benjamin: Selected Writings 1927-1930. Translated by Suhrkamp Verlag. Edited by Michael W. Jennings, Howard Eiland, and Gary Smith. Cambridge, MA: Harvard Univ. Press, 1999. 117-21.

\section{Notes}

1. Walter Benjamin, "Toys and Play," 120.

2. Ibid.

3. Ibid.

4. Ibid. 